\title{
INFLUENCE OF ROOTSTOCK ON NUTRIENT CONTENT IN GRAPE PETIOLES ${ }^{1}$
}

\author{
MARCO ANTONIO DALBÓ2 ${ }^{2}$ ENIO SCHUCK ${ }^{3}, \mathrm{CLORI} \mathrm{BASSO}^{4}$
}

ABSTRACT- Genetic diversity of rootstocks can affect nutrient uptake and the nutrient status of grapevines. The rootstock influence on nutrient content in grape petioles was evaluated on three rootstocks competition experiments carried out at Vale do Rio do Peixe region, in the state of Santa Catarina, Brazil, with the cultivars Niagara Rosada, Concord, and Isabella, grafted on different rootstocks. Two soil liming depths were also evaluated in the Isabella experiment. The greatest rootstock effect was observed on $\mathrm{K}$ and $\mathrm{Mg}$ content and $\mathrm{K} / \mathrm{Mg}$ ratio in the petioles. The Vitis vinifera $\mathrm{x}$ V. rotundifolia hybrid rootstocks VR 043-43 and VR 044-4 provided the highest $\mathrm{K} / \mathrm{Mg}$ values and self rooted Isabella the lowest $\mathrm{K} / \mathrm{Mg}$ ratio. The other tested rootstocks resulted in intermediate values. There was also significant effect on P content, but only in Niagara Rosada and Concord experiments. The depth of soil liming did not significantly affect $\mathrm{K}$ and $\mathrm{Mg}$ content in the Isabella experiment. The results indicate that rootstock must be considered for nutritional status evaluation and fertilizer recommendation regarding to $\mathrm{K}$ and $\mathrm{Mg}$.

Index terms: mineral nutrition, viticulture, potassium, magnesium.

\section{INFLUÊNCIA DO PORTA-ENXERTO NO TEOR DE NUTRIENTES NOS PECÍOLOS DE VIDEIRAS}

RESUMO - A diversidade genética dos porta-enxertos de videira pode afetar a absorção de nutrientes e o estado nutricional dos vinhedos. A influência do porta-enxerto nos teores de nutrientes em pecíolos de videira foi avaliada em três experimentos de competição de porta-enxertos instalados na região do Vale do Rio do Peixe-SC. As cultivares-copa foram Niagara Rosada e Concord, enxertadas sobre diversos portaenxertos. Para a cultivar Isabel, além do efeito do porta-enxerto, avaliou-se também a influência de duas profundidades de calagem do solo. Os maiores efeitos do porta-enxerto foram verificados nos teores de $\mathrm{Ke}$ $\mathrm{Mg}$ e na relação $\mathrm{K} / \mathrm{Mg}$ nos pecíolos. Os porta-enxertos híbridos de Vitis vinifera $x$ V. rotundifolia (VR 043-43 e VR 044-4) induziram as maiores relações $\mathrm{K} / \mathrm{Mg}$, ao passo que a cultivar Isabel (pé-franco) resultou nos menores valores desta relação. Os outros porta-enxertos testados resultaram em teores intermediários. Os níveis de calagem avaliados na cultivar Isabel não alteraram significativamente os teores de $\mathrm{K} \mathrm{e} \mathrm{Mg}$. Com relação aos demais nutrientes, houve efeito significativo para $\mathrm{P}$ apenas nos experimentos com as cultivares Niagara Rosada e Concord. Os resultados indicam que o porta-enxerto deve ser um fator a ser considerado na avaliação nutricional e recomendação de adubação da videira com relação aos nutrientes $\mathrm{K} \mathrm{e} \mathrm{Mg.}$

Termos de indexação: nutrição mineral, viticultura, potássio, magnésio.

\section{INTRODUCTION}

In southern Brazil most vineyards of Vitis vinifera $\mathrm{L}$. cultivars are planted using rootstocks resistant to phyloxera (Daktulosphaira vitifoliae).

Usually, grape rootstocks are hybrids of the American species V. riparia, V. rupestris, $V$. berlandieri and $V$. champinii. Recently, some rootstocks were obtained by crossing other species, such as $V$. caribaea and $V$. rotundifolia (also classified as Muscadinia rotundifolia). Some V. labrusca cultivars (Concord and Isabella), can be planted self-rooted because of their relative tolerance to phyloxera. This is common on Concord and Isabella vineyards in Southern Brazil.

The genetic diversity of rootstocks can also affect nutrient uptake and the nutrient status of the vines. It is already known that the rootstock affects grape leaf mineral contents, especially $\mathrm{K}$ and $\mathrm{Mg}$. In European competition trials some rootstocks, such as SO4 and 44-53M, showed high capacity to accumulate $\mathrm{K}$ in leaf tissue when compared to other current materials (DELAS; POUGET, 1979; BRANCADORO et al., 1995). These differences in nutrient absorption efficiency can be an important factor to

${ }^{1}$ (Trabalho 175-10). Recebido em: 30-07-2010. Aceito para publicação em: 31-03-2011.

${ }^{2}$ Pesquisador da Epagri - Estação Experimental de Videira, C. P. 21, CEP 89560-000 Videira-SC. E-mail: dalbo@epagri.sc.gov.br

${ }^{3}$ Pesquisador da Epagri - Estação Experimental de Videira, C. P. 21, CEP 89560-000 Videira-SC. E-mail: schuck@epagri.sc.gov.br

${ }^{4}$ Pesquisador da Epagri - Estação Experimental de Caçador, C. P. 591, CEP 89500-000 Caçador-SC. E-mail: clori@epagri.sc.gov.br 
estimate vineyard fertilizer requirements. The accumulation of $\mathrm{K}$ in the plant also reduces must acidity which affects the resulting wine, being a quality regulation factor (FREGONI, 1980; MPELASOKA et al., 2008). K content in grape petioles showed good correlation with must $\mathrm{K}$ content, increasing its importance in the evaluation of vineyards nutrient status (BRANCADORO et al., 1995).

In the 'Rio do Peixe Valley' region, State of Santa Catarina, Brazil, it was frequently found vineyards with low $\mathrm{K}$ content in leaf tissues, even with high $\mathrm{K}$ availability in the soil. In those cases, $\mathrm{Mg}$ content was usually high, resulting in very low $\mathrm{K} / \mathrm{Mg}$ ratio in leaves. This problem was first observed in a nutritional survey on vineyards of this region (DALBÓ et al., 1989). The first hypothesis to explain the results was the intense use of lime with low $\mathrm{Ca} / \mathrm{Mg}$ ratio for correcting soil acidity, which could affect absorption and the $\mathrm{K} / \mathrm{Mg}$ equilibrium in plants. Lately, it was verified that this disequilibrium was limited to self-rooted Isabella vineyards, which lead to the hypothesis that the problem had a genetic cause.

The objective of this study was to evaluate the effect of different rootstocks on nutrient content in grape petioles and their possible role on the nutritional problem involving $\mathrm{K}$ and $\mathrm{Mg}$.

\section{MATERIAL AND METHODS}

This study comprises three experiments set in 1987, at Videira Experiment Station, located in Videira, in the Midwest region of the State of Santa Catarina, Brazil. Two experiments had the objective to evaluate the behavior of two scion cultivars (Niagara Rosada e Concord) grafted on different rootstocks. The genetic origin of each rootstock and the combinations scion/rootstocks are presented in Table 1.

The third experiment, set with the cultivar Isabella, in a factorial $2 \times 3$ experimental design, consisted of two depths of liming in the main plots, and the subplots with Isabella, self-rooted or grafted on two rootstocks (SO4 and IAC 766). The liming treatments, applied in 1987, consisted in increasing soil $\mathrm{pH}$ to 6,0 (SMP method) in the soil layers 0-20 or 0-40 cm, which resulted in application and incorporation of 18 and 36 ton/ha of lime, respectively.

The experiments were set in a randomized block design, with five plants per plot and four replicates. The three experiments were previously evaluated for agronomic variables (Schuck et al., 2001). This nutritional study was carried out during the 2005/06 growing season.
The three experiments were carried out at closely located sites, with similar edaphoclimatic conditions. The soil is an Oxissol, classified as Alfisol dystrophic, according to the Brazilian Soil Classification System (EMBRAPA, 2006), developed from basalt rock. Originally, this soil had low $\mathrm{pH}$ (4.7), high clay (60-78\%) and organic matter content (4.5-6.0\%).

At veraison, seventy petioles per plot were sampled from the newest mature leaf for chemical analysis (COMISSÃO DE QUÍMICA E FERTILIDADE DO SOLO - RS/SC, 2004). Samples were quickly washed with tap water, oven dried at $70^{\circ} \mathrm{C}$ overnight, ground and analyzed for total content of $\mathrm{N}, \mathrm{P}, \mathrm{K}, \mathrm{Ca}, \mathrm{Mg}, \mathrm{Fe}, \mathrm{Mn}, \mathrm{Zn}, \mathrm{Cu}$ e B.

At the same time of petiole sampling, soil samples were collected in each plot, at the depths of $0-20 \mathrm{~cm}$ and $20-40 \mathrm{~cm}$, and analyzed for clay content, $\mathrm{pH}$ in water, SMP index, $\mathrm{P} \mathrm{e} \mathrm{K}$ by Melich-1 extractor, and exchangeable $\mathrm{Ca}, \mathrm{Mg}$ and $\mathrm{Al}$ extracted by $\mathrm{KCl}$ $1 \mathrm{~N}$.

Yield ( $\left.\mathrm{kg} \mathrm{plant}^{-1}\right)$, plant vigor, as material removed with winter pruning, were also evaluated.

Management practices were those currently used in vineyards of this region, and applied uniformly in all three experiments. The vineyards were installed in Pergola system, with plants spaced $3 \times 1,5 \mathrm{~m}$. Soil management consisted of chemical weed control in a 1 meter strip along the rows and mechanical weed control (mowing) the inter-row space. Yearly, fertilizers were uniformly applied in all plots. It was used a mixture of potassium chloride $\left(100 \mathrm{~kg} \cdot \mathrm{ha}^{-1}\right)+$ triple superphosphate $\left(100 \mathrm{~kg} \cdot \mathrm{ha}^{-1}\right)$ during the winter and ammonium nitrate $\left(150 \mathrm{~kg} \mathrm{ha}^{-1}\right)$ at the beginning of vegetation growth in the spring. Leaf diseases control was made using standard fungicides. Some of them contain micronutrients, such as dithiocarbamates ( $\mathrm{Mn}, \mathrm{Zn}$ ) and cupric fungicides $(\mathrm{Cu})$, which can have some interference in tissue mineral analysis.

\section{RESULTS E DISCUTION}

The soil analysis data (Table 2) show that the three experiments were conducted under similar soil fertility conditions. Only soil $\mathrm{pH}$ was slightly higher in the Isabella experiment than in the Niagara and Concord experiments. There were not significant differences among plots of the same experiment, indicating that comparisons among rootstocks were made in uniform soil fertility conditions.

Data from the experiments with the scion cultivars Niagara Rosada e Concord are presented in Table 3. The effect of rootstock on nutrient content in 
the petioles was more evident for $\mathrm{K}$ and $\mathrm{Mg}$ and for the ratio $\mathrm{K} / \mathrm{Mg}$. The $V$. vinifera $\mathrm{x} V$. rotundifolia $(\mathrm{VR})$ hybrid rootstocks, especially VR 043-43, resulted in the highest $\mathrm{K}$ and lower $\mathrm{Mg}$ contents. On the other hand, the cv. Isabella, when planted own-roots (Table 5) or as a rootstock (Table 3), gave the highest $\mathrm{Mg}$ and the lowest $\mathrm{K}$ contents. This effect was more evident when the $\mathrm{K} / \mathrm{Mg}$ ratio was considered. The other rootstocks showed $\mathrm{K}, \mathrm{Mg}$ and $\mathrm{K} / \mathrm{Mg}$ values between these two extremes, but the effect was not the same for the two scion cultivars. For instance, the 101-14 rootstock gave the second lowest $\mathrm{K} / \mathrm{Mg}$ ratio with Niagara Rosada and just an intermediary ratio with Concord.

The rootstock effect on $\mathrm{K} / \mathrm{Mg}$ equilibrium has relevant nutritional implications. In the Rio do Peixe Valley region, vineyards with low K content or low $\mathrm{K} / \mathrm{Mg}$ ratios in petioles are relatively common, even where soil $\mathrm{K}$ availability is medium to high. This situation is very common on self-rooted Isabella vineyards and probably is related to a high rate of absorption of $\mathrm{Mg}$ by the roots, depressing $\mathrm{K}$ intake. The correct choice of rootstocks could greatly reduce this problem. Currently used rootstocks (Paulsen 1103 and VR 043-43) result in higher K content than own-root Isabella (Table 3). However, vineyards of own-rooted Isabella are very common in this region. It is widely used for the juice and current wine industries. It is also resistant to Fusarium wilt, one of the major causes of plants death in this region.

The use of more efficient rootstocks in accumulating K, such as VR 043-43, eventually could cause an unbalance in the opposite side, i.e. to result in high $\mathrm{K} / \mathrm{Mg}$ ratio. Symptoms of $\mathrm{Mg}$ deficiency in leaves are commonly found in VR 043-43 rootstock plants at the end of cycle. It has been considered a minor problem compared to $\mathrm{K}$ deficiency, which has a more noticeable effect in reducing grape quality. However, some nutritional disequilibrium was observed on Cabernet Sauvignon vineyards grafted on this rootstock, with intense occurrence of bunch stem necrosis near harvest time. In these cases, $\mathrm{K} /$ $\mathrm{Mg}$ ratio reached values above 10 , which is a major factor inducing this physiologic disorder (DELAS, 1979).

The data also provide a better understanding of results from previously made nutritional surveys on vineyards in Southern Brazil, in the States of Rio Grande do Sul (Tonietto, 1994) and Santa Catarina (DALBÓ et al., 1989). The first one was carried on Concord vineyards (many own-rooted), with the conclusion that most of them had normal level of $\mathrm{K}$ contents. The Santa Catarina survey, in the Rio do Peixe Valley region, consisted mainly of own-rooted
Isabella vineyards, where it was found a high frequency of samples with K deficiency. Although this could be due to differences in soil fertility, genetic differences between these two cultivars seem to be the most important factor. Petioles of own-root Concord had relatively high $\mathrm{K}$, only lower than on the rootstock VR 043-43 (Table 3), which may explain the higher $\mathrm{K}$ content observed in that trial.

In the experiment with Isabella as scion cultivar, the rootstock had significant effect but doubling liming depth (and also liming dose) did not influence the nutritional equilibrium (Table 5). This is evidence that the differences in $\mathrm{K}$ and $\mathrm{Mg}$ contents in petioles were mostly due to genetics instead to soil characteristics.

Grape production was significantly correlated to $\mathrm{K} / \mathrm{Mg}$ ratio $(\mathrm{r}=0,79)$ and $\mathrm{Mg}$ content $(r=-0,88)$ in the 'Niagara Rosada' experiment but not in the 'Concord' experiment. There was no significant correlation between plant vigor, measured as pruned material, and production or nutrient content in any of the two experiments.

There was no significant rootstock influence on other nutrients but $\mathrm{P}$ (Table 3), whose effect was evident only in some scion cultivars tested. These effects seem result from specific interactions between scion and rootstock cultivars. Micronutrient accumulation in petioles was not affected by rootstock (Table 4). However, the results cannot be considered conclusive because micronutrient analysis may be affected by external factors. For instance, $\mathrm{Mn}, \mathrm{Zn}$ e $\mathrm{Cu}$ are components of many pesticides that may mask nutrient analysis data and increase experimental variability. Anyway, micronutrient deficiency is very uncommon in this region and the results can be considered normal.

Based on these results, rootstock should be considered an important factor to define fertilizers levels in vineyards. According to Delas (1979), the adequate range for $\mathrm{K} / \mathrm{Mg}$ in grape petioles at veraison is between 3 to 7 . Values below 1 indicate $\mathrm{K}$ deficiency and above $10, \mathrm{Mg}$ deficiency. Although values below 1 have been rare in the experiments evaluated, values below 3 were quite frequent, indicating possible response to potassium fertilization.

The $V$. vinifera $\mathrm{x} V$. rotundifolia hybrid rootstocks, which resulted in the highest values of $\mathrm{K} / \mathrm{Mg}$ ratio, frequently show $\mathrm{Mg}$ deficiency and excess of $\mathrm{K}$ at field conditions. On the other hand, vineyards of own-roots Isabella or possibly some rootstocks, such as $V$. riparia $\mathrm{x} V$. rupestris hybrids (101-14, Scharzman), are supposed to have more problems of K deficiency or would need higher doses 
of potassium fertilizers.

The influence of rootstock in the absorption of $\mathrm{K}$ and $\mathrm{Mg}$ in grapes was analyzed in previous studies (GALLO; RIBAS, 1962; DELAS; POUGET, 1979; ECEVIT et al., 1983; BOULAY, 1988; BRANCADORO et al., 1995; WOLPERT et al., 2005; CSIKÁSZ-KRIZSICS; DIÓFÁSI, 2008). However, these studies were made with traditional rootstocks which present amplitude of genetic diversity much lower than the present work. The Vitis rotundifolia hybrid rootstocks, which presented the highest $\mathrm{K} / \mathrm{Mg}$ values, are being used recently in commercial viticulture. The cultivar Isabella normally is not used as rootstock but it is commonly planted own-roots in Southern Brazil.

In the Rio do Peixe Valley region the VR 043-43, a Vitis rotundifolia hybrid rootstock, has been widely planted in the last years because of its good behavior in areas with problems of grapevine decline and high plant mortality rates. In this region ownrooted 'Isabella' vineyards still represent significant part of the viticulture. Consequently, it is a particular situation where vineyards with contrasting genetic characteristics regarding to $\mathrm{K}$ and $\mathrm{Mg}$ absorption and the equilibrium between these two nutrients are present in the same growing area. These differences should be considered to define fertilizers levels to be applied in each vineyard.

TABLE 1 - Genetic origin of grape rootstocks and scion/rootstock combinations used in the experiments.

\begin{tabular}{|c|c|c|c|c|}
\hline Rootstock & Genetic origin & Niagara Rosada & Concord & Isabella \\
\hline $043-43$ & Vitis vinifera $\times V$. rotundifolia & $\mathrm{x}$ & $\mathrm{x}$ & \\
\hline $044-4$ & $V$. vinifera $x V$. rotundifolia & & $\mathrm{x}$ & \\
\hline S04 & $V$. berlandieri $x$ V. riparia & $\mathrm{x}$ & & $\mathrm{x}$ \\
\hline $420 \mathrm{~A}$ & $V$. berlandieri $x V$. riparia & & $\mathrm{x}$ & \\
\hline R99 & $V$. berlandieri $x V$. rupestris & $\mathrm{x}$ & & \\
\hline Paulsen 1103 & $V$. berlandieri $x V$. rupestris & $\mathrm{x}$ & $\mathrm{x}$ & \\
\hline IAC 766 & V. caribaea $x$ Traviú (106-8) & $\mathrm{x}$ & $\mathrm{x}$ & $\mathrm{X}$ \\
\hline IAC 572 & V. caribaea $x$ 101-14 & $\mathrm{x}$ & & \\
\hline Concord & V. labrusca & & $\mathrm{x}$ & \\
\hline Isabella & V. labrusca & $\mathrm{x}$ & & $\mathrm{x}$ \\
\hline Dogridge & V. champinii & $\mathrm{x}$ & & \\
\hline Scharzman & $V$. riparia $x V$. rupestris & $\mathrm{x}$ & $\mathrm{x}$ & \\
\hline $101-14$ & V. riparia $x$ V. rupestris & $\mathrm{x}$ & $\mathrm{x}$ & \\
\hline $3309 \mathrm{C}$ & $V$. riparia $x V$. rupestris & & $\mathrm{x}$ & \\
\hline
\end{tabular}

TABLE 2 - Soil analysis data of each experiment (mean of all plots). Each scion cultivar represents one experiment.

\begin{tabular}{ccccccccc}
\hline Cultivar & $\begin{array}{c}\text { Depth } \\
(\mathrm{cm})\end{array}$ & $\begin{array}{c}\mathbf{p H} \\
\left(\mathrm{H}_{2} \mathrm{O}\right)\end{array}$ & $\begin{array}{c}\mathbf{P} \\
\left(\mathrm{mg} \mathrm{L}^{-1}\right)\end{array}$ & $\begin{array}{c}\text { K } \\
\left(\mathrm{mg} \mathrm{L}^{-1}\right)\end{array}$ & $\begin{array}{c}\text { O.M. } \\
(\%)\end{array}$ & $\mathbf{A l}$ & $\begin{array}{c}\text { Ca } \\
\left(\mathrm{cmol} \mathrm{dm}^{-3}\right)\end{array}$ & $\mathbf{M g}$ \\
\hline \multirow{2}{*}{ Niagara Rosada } & $0-20$ & 5.7 & 2.9 & 95 & 4.2 & 0.1 & 6.2 & 3.3 \\
& $20-40$ & 5.5 & 1.9 & 64 & 3.9 & 0.2 & 5.3 & 3.1 \\
Concord & $0-20$ & 5.4 & 3.6 & 114 & 4.1 & 0.3 & 5.8 & 2.8 \\
& $20-40$ & 5.2 & 1.5 & 72 & 3.9 & 0.6 & 4.6 & 2.3 \\
Isabella & $0-20$ & 6.2 & 1.8 & 133 & 4.4 & 0.0 & 10.3 & 5.1 \\
(liming up to 20cm) & $20-40$ & 5.5 & 1.3 & 117 & 3.6 & 0.4 & 8.2 & 4.3 \\
Isabella & $0-20$ & 6.4 & 2.3 & 107 & 4.2 & 0.0 & 11.4 & 5.7 \\
(liming up to 40cm) & $20-40$ & 6.2 & 2.8 & 80 & 4.3 & 0.0 & 10.6 & 5.5 \\
\hline
\end{tabular}


TABLE 3 - Yield, vigor (pruning material), macronutrients content $(\mathrm{g} / \mathrm{kg})$ and $\mathrm{K} / \mathrm{Mg}$ ratio in grape petioles of 'Niagara Rosada' e 'Concord' in relation to the rootstock.

\begin{tabular}{|c|c|c|c|c|c|c|c|c|}
\hline Rootstock & $\mathrm{N}$ & $\mathrm{P}$ & $\mathrm{K}_{(\mathrm{g}}$ & $\begin{array}{l}\text { Ca } \\
\left(g^{-1}\right)\end{array}$ & Mg & K/Mg & $\begin{array}{c}\text { Pruning material } \\
(\mathrm{kg} / \mathrm{pl})\end{array}$ & $\begin{array}{c}\text { Productivity } \\
\left(\mathrm{t} \mathrm{ha} \mathrm{h}^{-1}\right)\end{array}$ \\
\hline & & & \multicolumn{6}{|c|}{ Niagara Rosada } \\
\hline $043-43$ & $8.3 \mathrm{a}$ & $1.0 \mathrm{c}^{1}$ & $18.4 \mathrm{a}$ & $13.7 \mathrm{a}$ & $3.9 \mathrm{c}$ & $4.8 \mathrm{a}$ & $1.16 \mathrm{ab}$ & $30.3 \mathrm{a}$ \\
\hline SO4 & $6.6 \mathrm{a}$ & $1.0 \mathrm{c}$ & $15.5 \mathrm{ab}$ & $14.0 \mathrm{a}$ & $5.4 \mathrm{~b}$ & $2.9 \mathrm{~b}$ & $1.42 \mathrm{ab}$ & $23.4 \mathrm{~b}$ \\
\hline Paulsen 1103 & $6.7 \mathrm{a}$ & $1.8 \mathrm{ab}$ & $16.5 \mathrm{ab}$ & $13.8 \mathrm{a}$ & $5.8 \mathrm{~b}$ & $2.8 \mathrm{bc}$ & $0.97 \mathrm{~cd}$ & $21.7 \mathrm{~b}$ \\
\hline IAC766 & $6.9 \mathrm{a}$ & $1.3 \mathrm{c}$ & $17.4 \mathrm{a}$ & $15.1 \mathrm{a}$ & $6.3 \mathrm{~b}$ & $2.8 \mathrm{bc}$ & $2.05 \mathrm{a}$ & $16.9 \mathrm{bc}$ \\
\hline IAC572 & $7.5 \mathrm{a}$ & $1.1 \mathrm{c}$ & $11.9 \mathrm{~cd}$ & $14.3 \mathrm{a}$ & $5.6 \mathrm{~b}$ & $2.2 \mathrm{bc}$ & $2.03 \mathrm{a}$ & $18.5 \mathrm{bc}$ \\
\hline R99 & $7.0 \mathrm{a}$ & $2.0 \mathrm{a}$ & $12.1 \mathrm{~cd}$ & $12.7 \mathrm{a}$ & $5.8 \mathrm{~b}$ & $2.1 \mathrm{bc}$ & $1.59 \mathrm{ab}$ & $22.3 \mathrm{~b}$ \\
\hline Dog Ridge & $7.0 \mathrm{a}$ & $1.3 \mathrm{c}$ & $12.5 \mathrm{bc}$ & $13.7 \mathrm{a}$ & $6.4 \mathrm{~b}$ & $2.0 \mathrm{~cd}$ & $2.03 \mathrm{a}$ & $23.5 \mathrm{~b}$ \\
\hline Scharzman & $7.1 \mathrm{a}$ & $1.4 \mathrm{bc}$ & $11.7 \mathrm{~cd}$ & $12.9 \mathrm{a}$ & $6.1 \mathrm{~b}$ & $1.9 \mathrm{~d}$ & $1.17 \mathrm{bc}$ & $21.4 \mathrm{~b}$ \\
\hline $101-14$ & $6.8 \mathrm{a}$ & $1.1 \mathrm{c}$ & $10.5 \mathrm{~d}$ & $13.4 \mathrm{a}$ & $6.4 \mathrm{~b}$ & $1.7 \mathrm{de}$ & $1.12 \mathrm{de}$ & $19.6 \mathrm{~b}$ \\
\hline \multicolumn{9}{|c|}{ Concord } \\
\hline $043-43$ & $8.1 \mathrm{a}$ & $1.0 \mathrm{c}$ & $27.8 \mathrm{a}$ & $15.9 \mathrm{a}$ & $4.8 \mathrm{~b}$ & $6.1 \mathrm{a}$ & $0.25 \mathrm{ab}$ & $31.7 \mathrm{a}$ \\
\hline 044-4 & $8.1 \mathrm{a}$ & $1.0 \mathrm{c}$ & $18.8 \mathrm{~b}$ & $15.7 \mathrm{a}$ & $5.2 \mathrm{~b}$ & $4.2 \mathrm{~b}$ & $0.28 \mathrm{a}$ & $19.4 \mathrm{bc}$ \\
\hline $3309 \mathrm{C}$ & $9.5 \mathrm{a}$ & $1.1 \mathrm{bc}$ & $16.0 \mathrm{bc}$ & $15.2 \mathrm{a}$ & $5.6 \mathrm{ab}$ & $3.2 \mathrm{bc}$ & $0.16 \mathrm{bc}$ & $21.6 \mathrm{~b}$ \\
\hline Own root & $7.3 \mathrm{a}$ & $0.9 \mathrm{c}$ & $19.6 \mathrm{~b}$ & $16.3 \mathrm{a}$ & $6.1 \mathrm{ab}$ & $3.1 \mathrm{bc}$ & $0.13 \mathrm{c}$ & $12.1 \mathrm{~d}$ \\
\hline $101-14$ & $7.2 \mathrm{a}$ & $0.8 \mathrm{c}$ & $15.2 \mathrm{bc}$ & $15.2 \mathrm{a}$ & $5.5 \mathrm{ab}$ & $2.8 \mathrm{bc}$ & $0.19 \mathrm{abc}$ & $19.2 \mathrm{bc}$ \\
\hline Paulsen 1103 & $8.0 \mathrm{a}$ & $1.2 \mathrm{bc}$ & $15.0 \mathrm{bc}$ & $14.4 \mathrm{a}$ & $5.7 \mathrm{ab}$ & $2.6 \mathrm{bc}$ & $0.23 \mathrm{abc}$ & $22.9 \mathrm{~b}$ \\
\hline R99 & $8.3 \mathrm{a}$ & $1.6 \mathrm{a}$ & $13.8 \mathrm{c}$ & $14.7 \mathrm{a}$ & $6.2 \mathrm{ab}$ & $2.3 \mathrm{~cd}$ & $0.30 \mathrm{a}$ & $21.9 \mathrm{~b}$ \\
\hline Scharzman & $7.9 \mathrm{a}$ & $1.4 \mathrm{ab}$ & $14.5 \mathrm{c}$ & $15.9 \mathrm{a}$ & $6.7 \mathrm{ab}$ & $2.2 \mathrm{~cd}$ & $0.19 \mathrm{abc}$ & $19.6 \mathrm{bc}$ \\
\hline IAC 766 & $7.8 \mathrm{a}$ & $0.9 \mathrm{c}$ & $16.1 \mathrm{bc}$ & $16.9 \mathrm{a}$ & $7.6 \mathrm{a}$ & $2.1 \mathrm{~cd}$ & $0.31 \mathrm{a}$ & $15.5 \mathrm{~cd}$ \\
\hline $420-\mathrm{A}$ & $7.6 \mathrm{a}$ & $1.1 \mathrm{bc}$ & $9.3 \mathrm{~d}$ & $15.8 \mathrm{a}$ & $7.4 \mathrm{a}$ & $1.3 \mathrm{~d}$ & $0.23 \mathrm{abc}$ & $23.1 \mathrm{~b}$ \\
\hline Normal range $^{2}$ & $6,6-9,5$ & $1,6-2,5$ & $16-25$ & $11-20$ & $2,6-5,0$ & $3-7$ & & \\
\hline
\end{tabular}

${ }^{1}$ Means followed by the same letter in the column did not differ by the Duncan test at $5 \%$.

${ }^{2}$ Comissão de Química e Fertilidade do Solo - RS/SC (2004).

TABLE 4 - Micronutrients content in grape petioles 'Niagara Rosada' and 'Concord' in relation to the rootstock.

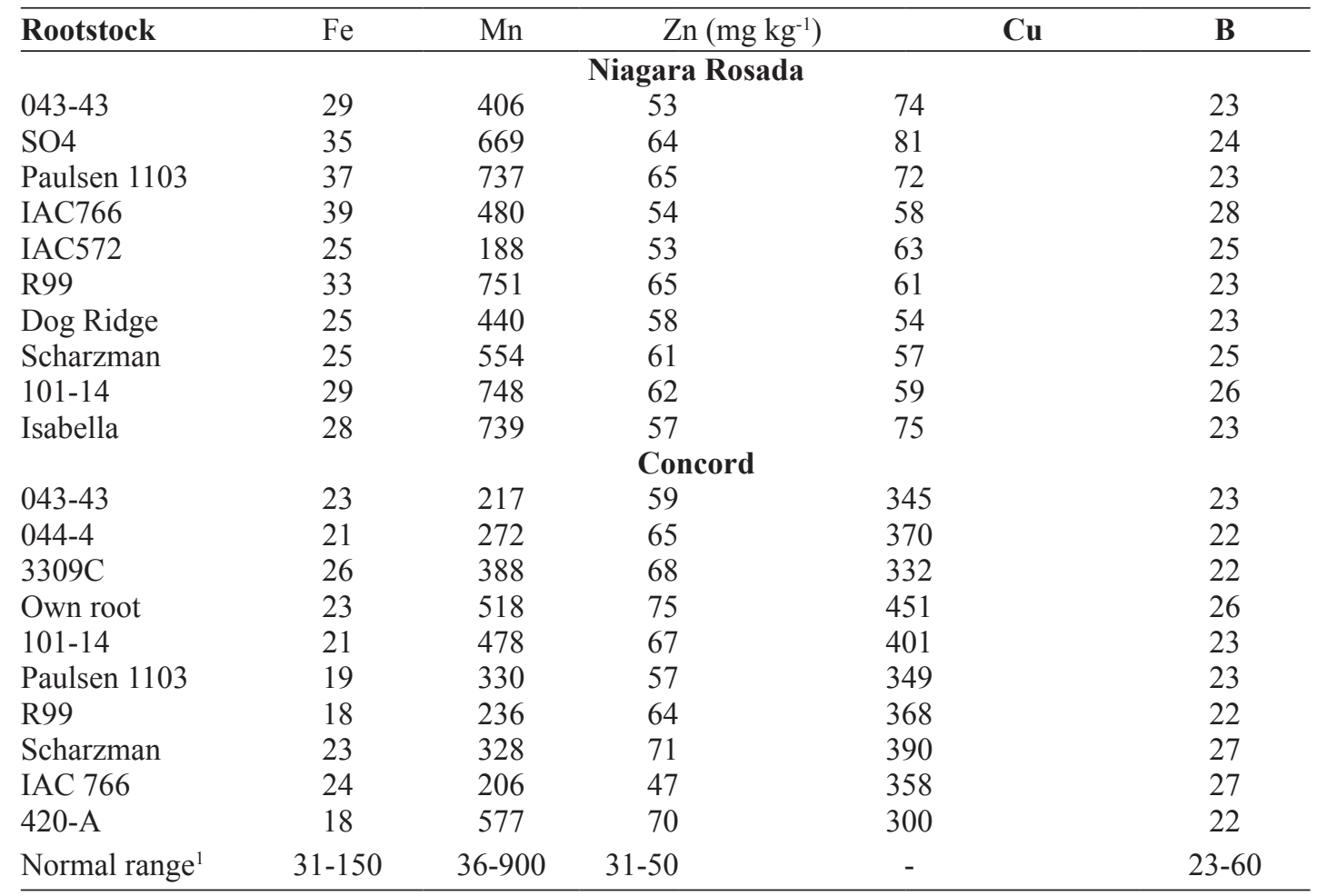

1. Comissão de Química e Fertilidade do Solo - RS/SC (2004). 
TABLE 5 - Macronutrients content and $\mathrm{K} / \mathrm{Mg}$ ratio in grape petioles of 'Isabella' in relation to the rootstock and depth of liming.

\begin{tabular}{lccccccc} 
Rootstock & $\begin{array}{c}\text { Depth of liming } \\
\text { (cm) }\end{array}$ & $\mathbf{N}$ & $\mathbf{P}$ & $\mathbf{K}$ & $\mathbf{C a}$ & $\mathbf{M g}$ & $\mathbf{K} / \mathbf{M g}$ \\
\hline Isabella own root & $0-20$ & $-\ldots$ & & & & & \\
SO4 & $0-20$ & $7,8 \mathrm{~b}^{1}$ & $2,8 \mathrm{a}$ & $16,3 \mathrm{~b}$ & 17,2 & $10,8 \mathrm{a}$ & $1,6 \mathrm{~b}$ \\
IAC 766 & $0-20$ & $7,7 \mathrm{~b}$ & $2,1 \mathrm{a}$ & $21,9 \mathrm{a}$ & 19,7 & $8,3 \mathrm{~b}$ & $2,7 \mathrm{a}$ \\
Isabella own root & $0-40$ & $8,7 \mathrm{a}$ & $2,8 \mathrm{a}$ & $16,3 \mathrm{~b}$ & 18,7 & $10,9 \mathrm{a}$ & $1,6 \mathrm{~b}$ \\
SO4 & $0-40$ & $8,1 \mathrm{a}$ & $2,7 \mathrm{a}$ & $20,2 \mathrm{a}$ & 19,7 & $6,9 \mathrm{~b}$ & $3,0 \mathrm{a}$ \\
IAC 766 & $0-40$ & $8,5 \mathrm{a}$ & $2,3 \mathrm{a}$ & $23,7 \mathrm{a}$ & 19,0 & $7,5 \mathrm{~b}$ & $3,3 \mathrm{a}$ \\
\hline
\end{tabular}

${ }^{1}$ Means followed by the same letter in the column did not differ by the Duncan test at $5 \%$.

\section{CONCLUSIONS}

$1-\mathrm{K}$ and $\mathrm{Mg}$ content in grape petioles are significantly influenced by the rootstock.

2 - The $V$. vinifera $\mathrm{x} V$. rotundifolia hybrids rootstocks (VR 043-43 and VR 044-4) lead to the highest values of $\mathrm{K} / \mathrm{Mg}$ ratio in grape petioles, while Isabella, own-rooted or as a rootstock, resulted in the lowest values of this ratio.

3 - Liming depth did not affect $\mathrm{K}$ e $\mathrm{Mg}$ content and $\mathrm{K} / \mathrm{Mg}$ ratio in grape petioles.

4 - Rootstock should be considered for $\mathrm{K}$ and $\mathrm{Mg}$ nutritional status evaluations, and to estimate the fertilizer requirement of vineyards.

\section{REFERENCES}

BRANCADORO, L.; VALENTI, L.; REINA, A. Rootstock effect on potassium content of grapevine. Acta Horticulture, Wageningen, n.383, p.115-124, 1995.

BOULAY, H. Nutrition potassique et magnesiènne de la vigne. Les effects du porte-greffe et du cépage. Arboriculture Frutiére, Paris, v.35. n.408, p. 38-44, 1988.

COMISSÃO DE QUÍMICA E FERTILIDADE DO SOLO. Manual de adubação e de calagem para os Estados do Rio Grande do Sul e de Santa Catarina. 10. ed. Porto Alegre: SBCS -Núcleo Regional Sul, 2004. 400p.
CSIKÁSZ-KRIZSICS, A.; DIÓFÁSI, L. Effects of rootstock-scion combinations on macroelements availability of the vines. Journal of Central European Agriculture, Plovdiv, v.8, n.3, p.495-503, 2008.

DALBÓ, M.A.; BECKER, M.; BASSO, C.; STUCKER, H. Levantamento do estado nutricional da videira em Santa Catarina por análise de solo e tecido. Revista Brasileira de Ciência do Solo, Campinas, v.13, p.335-340, 1989.

DELAS, J. Place d'analyse foliaire dans l'elaboration du conseil du fumure en viticulture. Colloque sur Diagnostic Foliaire, CNRF Champenoux, p. $107-$ 116, 1979.

DELAS, J.; POUGET, R. Influence du greffage sur la nutrition minerale de la vigne. Consequences sur la fertilization. Connaissance de la Vigne et du Vin, Bordeaux, v.13. n.4, p.241-261, 1979.

ECEVIT, F. M.; ILTER, E.; KISMALI, I. Effects de certains porte-greffes américains sur la nutrition minerále de la vigne. Le Progrés Agricole et Viticole, Paris, v.101, p.509-520, 1983.

EMBRAPA - Empresa Brasileira de Pesquisa Agropecuária. Sistema brasileiro de classificação de solos. 2.ed. Rio de Janeiro: Embrapa Solos, 2006. 306p.

FREGONI, M. Nutrizione e fertilizzazione della vite. Bologna: Edagricole, 1980. 418 p.

GALLO, J. R.; RIBAS, W. C. Análise foliar de diferentes combinações enxerto-cavalo, para dez variedades de videira. Bragantia, Campinas, v.21, n.24, p.397-410, 1962. 
MPELASOKA, B.S.; SCHACHTMAN, D.P.; TREEBY, M.T.; THOMAS, M.R. A review of potassium nutrition in grapevines with special emphasis on berry accumulation. Australian Journal of Grape and Wine Research, Adelaide, v.9, n.3, p.154-168, 2008.

SCHUCK, E.; DALBÓ, M.A.; ROSIER, J.P.; DUCROQUET, J.P.H.J. Porta-enxertos para a cultura da videira. In: ENCONTRO NACIONAL SOBRE FRUTICULTURA DE CLIMA TEMPERADO, 4 ., 2001, Fraiburgo. Anais... Caçador: Epagri, 2001. p.122-132.
TONIETTO, J. Diagnóstico nutricional das videiras Isabel e Concord através da análise foliar. Revista Brasileira de Fruticultura, Jaboticabal, v.16, n.1, p.185-194, 1994.

WOLPERT, J.A.; SMART, D.R.; ANDERSON, M. Lower Petiole Potassium Concentration at Bloom in Rootstocks with Vitis berlandieri Genetic Backgrounds. American Journal of Enology and Viticulture, Davis, v.56, n.2, p.163-169, 2005. 